\title{
PREDIKTORY ZMIEN FUNKČNÉHO A KOGNITÍVNEHO STAVU PACIENTOV PO CMP
}

\author{
Sollár Tomáš ${ }^{1}$, Katrušín Boris ${ }^{1}$, Romanová Martina² ${ }^{2}$ Solgajová Andrea ${ }^{3}$ \\ ${ }^{1}$ Katedra psychologických vied, Fakulta sociálnych vied a zdravotníctva, Univerzita \\ Konštantína Filozofa v Nitre \\ 2Ústav aplikovanej psychológia, Fakulta sociálnych vied a zdravotníctva, Univerzita \\ Konštantína Filozofa v Nitre \\ ${ }^{3}$ Katedra ošetrovatel'stva, Fakulta sociálnych vied a zdravotníctva, Univerzita \\ Konštantína Filozofa v Nitre \\ tsollar@ukf.sk, asolgajova@ukf.sk, boris.katrusin@ukf.sk, mromanova@ukf.sk
}

\begin{abstract}
Abstrakt
Východiská: Rekoncalescencia pacientov po prekonaní cievnej mozgovej príhody (CMP) je kl'účová pre ich d'alší život. Poznanie prediktorov pozitívnych zmien funkčného a kognitívneho stavu môže prispiet' kefektívnejšej starostlivosti o pacientov po CMP.

Ciel': Ciel'om štúdie je skúmat' zmeny vo funkčnom a kognitívnom stave a ich predikciu psychologickými premennými (depresia, úzkost', kvalita života, proaktívne zvládanie a osobnostné charakteristiky) hodnotenými v akútnej fáze ochorenia.

Metódy: Výberovú vzorku tvorilo spolu 127 pacientov po prekonaní CMP, z toho $60 \%$ mužov, priemerný vek pacientov bol 67,1 roka. Prvé meranie bolo realizované v akútnej fáze 72 hodín po prekonaní CMP; druhé meranie pri kontrole do 1 roka po prekonaní CMP. Celkový počet opakovaných meraní $n=57$, pre kombináciu všetkých sledovaných premenných $\mathrm{n}=40$. Pre zber dát boli použité Barthel škála ADL, MiniMental State Examination, dotazníky Hospital Anxiety and Depression Scale, Stroke Specific Quality of Life Scale, Utrecht Proactive Competence Coping Scale a Mini IPIP. Výskum bol schválený Etickou komisiou.

Výsledky: Zo sledovaných psychologických prediktorov funkčného stavu sa ukazujú hodnotenie kvality života v akútnej fáze po cievnej mozgovej príhode a osobnostná charakteristika otvorenost' voči skúsenosti. Zmeny kognitívneho stavu v akútnej fáze a v čase prvej kontrole sa ukazujú štatisticky nevýznamné. Výsledky naznačujú, že prípadné zmeny nie sú štatisticky významne predikovatel'né sledovanými psychologickými premennými.

Implikácie: Vnímanie kvality života vakútnej fáze po CMP môže predpovedat' pozitívne zmeny funkčného stavu pacientov. Poznanie d'alších potenciálnych prediktorov môže prispiet’ k efektívnejšej starostlivosti o pacientov po CMP.
\end{abstract}

Kl'účové slová: Cievna mozgová príhoda. Funkčný stav. Osobnost'. Kvalita života. Úzkost'. Depresia.

\section{ÚVOD}

Cievna mozgová príhoda je jednou z hlavných príčin smrti u dospelých na celom svete a významnou mierou tiež prispieva $\mathrm{k}$ invalidite u dospelých, ktorá spôsobuje značné ekonomické zat'aženie (Feigin, Roth \& Naghavi et al., 2016; Wang, Jiang \& Sun et al., 2017). V populácii sa výskyt cievnej 
mozgovej príhody zvyšuje. Navyše sa ukazuje trend, že cievna mozgová príhoda sa vyskytuje u jedincov stále mladšieho veku (Maaijwee et al., 2014; Nawaz, Eide, Fromm et al., 2019). V súvislosti s mladými aj dospelými l'ud'mi má značný socioekonomický vplyv spojený s vysokými nákladmi na zdravotnú starostlivost' a obrovskou stratou produktivity práce (Wang, Jiang \& Sun et al., 2017, Wang, W. Zhang, X. Yang et al., 2019).

Vd'aka pokroku v medicíne a technike je možné zachránit' čoraz viac l'udí, dôsledkom čoho je narastajúci počet tých, ktorí zostávajú žit’ s trvalými následkami alebo si vyžadujú dlhodobú starostlivost' (Chiang et al., 2015). Títo pacienti často trpia fyzickými a emocionálnymi problémami (Haagsma et al., 2015; Lin et al., 2010), kognitívnymi deficitmi (Grauwmeijer et al., 2018; Yeoh et al., 2019) a behaviorálnymi a sociálnym zmenami a dôsledkami (Azouvi et al., 2016; Lin et al., 2010) ktoré negatívne ovplyvňujú kvalitu života (QoL) (Andelic et al., 2009; Forslund et al., 2013; Pagnini et al., 2019; Yeoh et al., 2019).

Uzdravenie pacientov s ischemickou cievnou mozgovou príhodou závisí nielen od fyzickej rehabilitácie, ale aj od ich psychického stavu (Ekker, Boot \& Singhal et al. 2018, Hackett el al., 2014). Nedávne štúdie ukázali, že psychologický stav po mozgovej príhode zohráva dôležitú úlohu pri zotavovaní sa u pacientov s ischemickou cievnou mozgovou príhodou v prostredí klinickej praxe (Robinson, \& Jorge, 2016). Medzi psychologické premenné, ktoré je dôležité spomenút' patrí depresia, stres a jeho zvládanie, sociálna opora, hostilita, sebaúčinnost' ale aj osobnostné premenné - extroverzia/introverzia, optimizmus/pesimizmus, umiestnenie kontroly ku zdraviu a iné. Tie sa podpisujú na rekonvalescencii a priamo či nepriamo aj na kvalite života týchto pacientov. Predchádzajúce zistenia hovoria o tom, že stabilný emocionálny stav pacientov, otvorenost', svedomitost' a proaktívne zvládanie súvisí s funkčným zotavení a kvalitnou života. Naopak depresia a úzkost' s nižším funkčným zotavením a kvalitou života v akútnej fáze ochorenia (Sollár et al., in press). Psychologická premenná nádej predstavovala štatisticky významný prediktor funkčného zotavenia 3 mesiace po hospitalizácii (Kortte et al., 2012).

Vzhl'adom na aktuálny stav vývoja liečby a narastajúci počet preživších je potrebné rozumiet’ týmto mechanizmom aj v strednodobom a dlhodobom horizonte po CMP.

Ciel'om štúdie je skúmat' zmeny vo funkčnom a kognitívnom stave a ich predikciu psychologickými premennými (depresia, úzkost', kvalita života, proaktívne zvládanie a osobnostné charakteristiky) hodnotenými v akútnej fáze ochorenia.

\section{METÓDY}

Výberovú vzorku tvorilo spolu 127 pacientov po prekonaní CMP, hospitalizovaných na neurologickej klinike, z toho $60 \%$ mužov a $40 \%$ žien s najväčším výskytom ischemickej CMP (86\%). Priemerný vek pacientov bol 67,1 roka $\left(\mathrm{SD}_{\mathrm{vek}}=12,8\right)$. Meranie bolo realizované v dvoch časových bodoch: 1 . v akútnej fáze 72 hodín po prekonaní CMP; 2 . pri kontrole do 1 roka po prekonaní CMP, resp. prepustení po hospitalizácii (priemerný počet dní M=80, $\mathrm{SD}=51,6$ ). Celkový počet opakovaných meraní n=57, pre kombináciu všetkých sledovaných premenných n=40.

Zarad'ujúcimi kritériami do výberového súboru boli: lekárska diagnóza CMP, lucidné vedomie, schopnost' komunikácie, hospitalizácia maximálne 5. deň od CMP, vek $\geq 18$ rokov, skóre NIHSS (National Institutes of Health Stroke Scale) $\geq 1$, vyjadrený informovaný súhlas. Vylučujúcimi kritériami boli: iné závažné ochorenia (rakovina, demencia, a. i.), porucha vedomia a neschopnost' dorozumievania, exitus. Zber dát prebiehal v období august 2020 -november 2021. Výskum bol schválený etickou komisiou nemocnice.

Funkčný stav bol hodnotený na základe Barthel škály ADL (The Barthel Index of Activities of Daily Living; Mahoney, Barthel, 1965). Posudzuje funkčnú nezávislost’ v desiatich aktivitách denného života, pričom vanalýze bolo použité sumárne hrubé skóre. Celkové skóre je hodnotené 
nasledovne: 0-40 - vysoká závislost', 45-60 stredná závislost', nad 60 - závislost' l’ahšieho stupňa, nad 100 bodov nezávislost' (Bóriková, 2010).

Krátky test kognitívnych funkcií (Mini-Mental State Examination - MMSE; Folstein, 1975; Molloy et al., 1991) obsahuje 30 položiek, ktoré testujú kognitívne funkcie - orientáciu, pamät', výbavnost', pozornost' a počítanie, reč (plynulost'), porozumenie reči, schopnost' opakovat') a zrakovopriestorové funkcie.

Depresia a úzkost' boli merané prostredníctvom dotazníka Hospital Anxiety and Depression Scale (HADS; Zigmond and Snaith, 1983). Dotazník obsahuje 14 položiek; pozostáva z dvoch subškál HADS-A (úzkost') a HADS-D (depresia). 7 položiek je zameraných na hodnotenie úzkosti a 7 na hodnotenie depresie. Na každú položku respondent odpovedá prostredníctvom Likertovej škály od 0 do 3, ako sa cítil v priebehu posledného týždňa (počas hospitalizácie). Pre účely analýz bolo použité hrubé skóre. Vnútorná konzistencia škál bola: HADS-A $\alpha=0,71$, a HADS-D $\alpha=0,64$.

Skrátená verzia dotazníka Stroke Specific Quality of Life Scale (SS-QoL-12; Post et al., 2011) bola použitá na zist'ovanie kvality života pacientov po CMP. Dotazník obsahuje 12 položiek: a) sebaopatera, b) pohyblivost', c) motorika horných končatín, d) reč, e) zrak, f) práca, g) myslenie, h) rodinné role, ch) sociálne role, i) osobnost', j) nálada a k) energia. Pre analýzy bolo použité sumárne skóre všetkých položiek $(\alpha=0,87)$.

Pre hodnotenie proaktívneho zvládania bola použitá Utrecht Proactive Competence Coping Scale (Bode, Thoolen, de Ridder, 2008). Ide o 21-položkový nástroj s dobrou realiabilitou ( $\alpha=0,83-0,95)$. Dotazník Mini IPIP (International Personality Item Pool) je sebavýpoved'ový dotazník na hodnotenie piatich osobnostných charakteristík (faktorov), vychádzajúci z modelu Big Five (Teória vel'kej pät'ky). Prostredníctvom dotazníka je možné hodnotit' extraverziu, neurotizmus, otvorenost' voči skúsenosti, prívetivost' a svedomitost'. Obsahuje 20 položiek, pre každý faktor osobnosti sú 4 položky. Hodnotenie prebieha na Likertovej škále od 1 do 5 , kde 1 je vôbec nevystihuje a 5 úplne vystihuje (Hullová \& Duriš 2016). Reliabilita pre všetkých pät' faktorov sa pohybovala v rozpätí $(\alpha=0,73-0,90)$.

Na analýzu regresných modelov sme použli štatistický softvér SPSS 22.0. Pre testovanie modelov predikcie ADL sme použili metódy viacnásobnej lineárnej regresnej analýzy (multiple linear regression - MLR; Tabachnick \& Fidell 2007).

\section{VÝSLEDKY}

Výsledky odpovedajú na otázku skúmania psychologických prediktorov zmien funkčného a kognitívneho stavu pacientov po prekonaní CMP. Skúmame dva modely, v jednom funkčný, resp. kognitívny stav predikujú (depresivita a úzkost', kvalita života, proaktívne zvládanie; $M_{1}, M_{3}$ ), $v$ druhom rovnaké prediktory spolu s osobnostnými charakteristikami; $M_{2}, M_{4}$ ). Na testovanie modelov predikujúcich zmeny vo funkčnom stave (ADL) sme použili krokovú metódu viacnásobnej lineárnej regresnej analýzy (metódu Stepwise). Na testovanie modelov predikujúcich zmeny v kognitívnom stave (MMSE) sme použili štandardnú metódu viacnásobnej lineárnej regresnej analýzy (metódu Enter).

\section{Funkčný stav}

Pre testovanie prvých dvoch modelov sme použili krokovú metódu (MLR), ktorá navrhuje modely na základe preukázania štatisticky významného prediktora. Ak v nasledujúcom kroku analýza neidentifikuje štatisticky významný prediktor, d’alší model neponúkne. Tabul'ky uvádzame v poradí: celkové zhodnotenie modelov (tabul'ka 1), regresné koeficienty štatisticky významných prediktorov (tabul'ka 2), koeficienty prediktorov, ktoré boli z modelu vylúčené (tabul'ka 3).

Tabul'ka 1. Celkové zhodnotenie modelov predikujúcich funkčný stav (ADL) 


\begin{tabular}{|l|c|c|c|c|}
\hline & $\mathrm{R}$ & $\mathrm{Adj} \mathrm{R}^{2}$ & $\mathrm{~F}$ & $\mathrm{p}$ \\
\hline $\begin{array}{l}\text { Model 1 (Kvalita života, Úzkost', Depresia, } \\
\text { Proaktívne zvládanie) }\end{array}$ & 0,316 & 0,100 & 4,22 &, 047 \\
\hline $\begin{array}{l}\text { Model 2 (Kvalita života, Úzkost', Depresia, } \\
\text { Proaktívne zvládanie, Neurotizmus, Extraverzia, } \\
\text { Otvorenost', Prívetivost', Svedomitost') }\end{array}$ & 0,322 & 0,104 & 4,41 &, 042 \\
\hline
\end{tabular}

$\mathrm{R}$ - koeficient viacnásobnej korelácie, Adj $\mathrm{R}^{2}$ - Adjustovaný reziduál R², F - F-test, p - štatistická signifikancia

Rozdiel hodnotenia funkčného stavu pacientov v akútnej fáze a pri prvej kontrole bol štatisticky významný ( $\left.\mathrm{M}_{1}=71,8, \quad \mathrm{SD}_{1}=26,9 ; \mathrm{M}_{2}=81,4, \quad \mathrm{SD}_{2}=28,5 ; \mathrm{t}_{(53)}=2,03 ; \mathrm{p}=0,047\right)$. Model so štyrmi vstupnými prediktormi (Model 1) je štatisticky významný a vysvetl'uje $10 \%$ variability skúmanej premennej. Kroková metóda ponúkla jeden model, pričom štatisticky významný prediktor zmeny funkčného stavu sa ukazuje iba subjektívne hodnotená kvalita života v akútnej fáze po CMP ( $\beta=-$ ,316; $p=, 047 ;$ Tabul'ka 2). Čím hodnotia pacienti kvalitu života v akútnej fáze horšie, tým nastáva väčšie zlepšenie funkčného stavu. Zostávajúce tri premenné nie sú štatisticky významné prediktory (Tabul'ka 3).

Po pridaní piatich osobnostných premenných do modelu (Model 2) analýza tiež ponúkla jeden štatisticky významný model predikujúci cca $10 \%$ variability skúmanej premennej. Na rozdiel od predošlého modelu je však štatisticky významná premenná Otvorenost' ( $\beta=-, 322 ; p=, 042$; Tabul'ka 2). Čím sú pacienti menej otvorení, tým nastáva väčšie zlepšenie funkčného stavu. Zostávajúce premenne nie sú štatisticky významné prediktory (Tabul'ka 3).

Tabul'ka 2. Regresné koeficienty prediktorov v modeloch predikcie ADL

\begin{tabular}{|ll|c|c|c|c|c|}
\hline & & $\mathrm{B}$ & $\mathrm{SE}(\mathrm{B})$ & $\beta$ & $\mathrm{t}$ & $\mathrm{p}$ \\
\hline Model 1 & Kvalita života & $-13,852$ & 6,743 &,- 316 & $-2,054$ &, 047 \\
\hline Model 2 & Otvorenost' & $-3,595$ & 1,712 &,- 322 & $-2,100$ &, 042 \\
\hline
\end{tabular}

Pozn.: B - neštandardizovaný regresný koeficient, SE(B) - štandardná chyba neštandardizovaného regresného koeficientu, $\beta$ - štandardizovaný regresný koeficient

Pri druhom testovanom modeli sú dva prediktory síce štatisticky nevýznamné (Svedomitost' $p=, 061$ a Kvalita života $p=, 076$ ), pri opakovanom skúmaní by sme mohli zistit’ efekt pri väčšej vel'kosti vzorky. Interpretáciu výsledkov uvádzame v diskusii. 
Tabul'ka 3. Štatisticky nevýznamné prediktory (M1,M2)

\begin{tabular}{|c|c|c|c|c|c|}
\hline & & Beta In & $\mathrm{t}$ & $\mathrm{p}$ & Partial Corr. \\
\hline \multirow{3}{*}{ Model 1} & Úzkost' &,- 078 &,- 394 & ,696 &,- 065 \\
\hline & Depresia & 043 & ,226 & ,822 & ,037 \\
\hline & Proaktívne zvládanie &,- 088 &,- 472 & ,640 &,- 077 \\
\hline \multirow{8}{*}{ Model 2} & Neruotizmus &,- 004 &,- 025 & 980 &,- 004 \\
\hline & Extraverzia &,- 104 &,- 653 & ,518 &,- 107 \\
\hline & Prívetivost' & 022 & 140 & ,890 & 023 \\
\hline & Svedomitost' &,- 287 & $-1,932$ &, 061 &,- 303 \\
\hline & Úzkost' & ,058 & 371 & ,713 & 061 \\
\hline & Depresia & 052 & 318 & ,752 & 052 \\
\hline & Kvalita života &,- 275 & $-1,828$ & ,076 &,- 288 \\
\hline & Proaktívne zvládanie &,- 048 &,- 288 & 775 &,- 047 \\
\hline
\end{tabular}

Pozn.: Beta In - štandardizovaný regresný koeficient prírastku premennej pre model; Závislá premenná: ADL

\section{Kognitívny stav}

Pre testovanie dvoch modelov predikujúcich kognitívny stav sme použili štandardnú metódu (MLR), ked’že kroková metóda neponúkla žiadny model. Tabul'ky uvádzame v poradí: celkové zhodnotenie modelov (tabul'ka 4), regresné koeficienty všetkých prediktorov (tabul'ka 5).

Tabul'ka 4. Celkové zhodnotenie modelov predikujúcich kognitívny stav (MMSE)

\begin{tabular}{|l|c|c|c|c|}
\hline & $\mathrm{R}$ & Adj R & $\mathrm{F}$ & $\mathrm{p}$ \\
\hline $\begin{array}{l}\text { Model 3 (Kvalita života, Úzkost', Depresia, } \\
\text { Proaktívne zvládanie) }\end{array}$ & 0,106 & 0,011 & 0,06 &, 992 \\
\hline $\begin{array}{l}\text { Model 4 (Kvalita života, Úzkost', Depresia, } \\
\begin{array}{l}\text { Proaktívne zvládanie, Neurotizmus, Extraverzia, } \\
\text { Otvorenost', Prívetivost', Svedomitost') }\end{array}\end{array}$ & 0,478 & 0,229 & 0,56 &, 811 \\
\hline
\end{tabular}

$\mathrm{R}$ - koeficient viacnásobnej korelácie, Adj $\mathrm{R}^{2}$ - Adjustovaný reziduál R2 , F - F-test, p - štatistická signifikancia

Rozdiel hodnotenia kognitívneho stavu pacientov $\mathrm{v}$ akútnej fáze a pri prvej kontrole bol štatisticky nevýznamný ( $\left.\mathrm{M}_{1}=21,4, \mathrm{SD}_{1}=4,7 ; \mathrm{M}_{2}=21,8, \mathrm{SD}_{2}=8,4 ; \mathrm{t}_{(27)}=0,45 ; \mathrm{p}=0,731\right)$. Model so štyrmi vstupnými prediktormi (Model 3) je štatisticky nevýznamný. Rovnako z hodnotenia všetkých prediktorov vidiet', že ani jeden nie je štatisticky významný prediktor (Tabul'ka 5).

Model so všetkými prediktormi (Model 4) nie je štatisticky významný. Rovnako ako pri predošlom modeli ani jeden prediktor nie je štatisticky významný (Tabul'ka 5). 
Tabul'ka 5. Regresné koeficienty prediktorov v modeloch predikcie MMSE

\begin{tabular}{|cl|c|c|c|c|c|}
\hline & & $\mathrm{B}$ & $\mathrm{SE}(\mathrm{B})$ & $\beta$ & $\mathrm{t}$ & $\mathrm{p}$ \\
\hline \multirow{2}{*}{ Model 3 } & Úzkost' &,- 110 &, 474 &,- 060 &,- 232 &, 819 \\
& Lepresia &, 318 &, 867 &, 138 &, 367 &, 717 \\
& Kvalita života &, 988 & 3,968 &, 102 &, 249 &, 806 \\
& Proaktívne zvládanie &,- 866 & 4,695 &,- 055 &,- 185 &, 855 \\
\hline \multirow{2}{*}{ Neurotizmus } &, 122 &, 740 &, 056 &, 165 &, 871 \\
& Extraverzia &,- 126 &, 641 &,- 065 &,- 197 &, 846 \\
& Otvorenost' &,- 648 &, 769 &,- 244 &,- 843 &, 411 \\
& Prívetivost' &,- 251 &, 653 &,- 103 &,- 384 &, 705 \\
Model 4 & Svedomitost' & $-1,142$ &, 735 &,- 511 & $-1,553$ &, 139 \\
& Úzkost' &,- 215 &, 597 &,- 118 &,- 360 &, 723 \\
& Depresia &, 402 &, 960 &, 175 &, 418 &, 681 \\
& Kvalita života & 2,170 & 4,427 &, 224 &, 490 &, 630 \\
& Proaktívne zvládanie & 5,102 & 6,035 &, 324 &, 845 &, 410 \\
\hline
\end{tabular}

Pozn.: B - neštandardizovaný regresný koeficient, SE(B) - štandardná chyba neštandardizovaného regresného koeficientu, $\beta$ - štandardizovaný regresný koeficient

\section{DISKUSIA}

Poznanie prediktorov funkčného stavu pacientov rôznych diagnóz môže napomáhat' zlepšenej kvalite poskytovanej starostlivosti (Donellan et al., 2010). Prekonanie cievnej mozgovej príhody predstavuje pre pacientov výrazný zásah do života, pričom môžu byt' negatívne ovplyvnené ako aktivity denného života, tak aj kognitívny výkon.

Zmeny vaktivitách denného života smerom od závislosti k nezávislosti sa podl'a výskumov vyskytujúhlavne počas prvého roka po mozgovej príhode (Rejnö et al., 2019). Naše výsledky naznačujú podobné zlepšenie, pričom interval sledovaného obdobia bol od cca 1 do 9 mesiacov. Zmeny sa podl'a zistení (Rejnö et al., 2019) vyskytujú aj 5 rokov po CMP.

Po CMP sú bežné kognitívne poruchy a strata pamäti. Približne u $30 \%$ pacientov s cievnou mozgovou príhodou sa demencia rozvinie do 1 roka od začiatku cievnej mozgovej príhody. CMP ovplyvňuje kognitívnu oblast', ktorá zahŕňa pozornost', pamät', jazyk a orientáciu (Al-Qazzaz et al., 2014). Podla našich výsledkov nedošlo k štatisticky významným rozdielom v hodnotení kognitívneho stavu pacientov. Limitom zistení je však pomerne malý výskumný súbor. Zistenia je tak potrebné podrobit' d'alšiemu skúmaniu, možno aj z hl'adiska sledovania variability samotného kognitívneho výkonu, nakol'ko naše zistenia naznačujú možnú väčšiu variabilitu výkonu po čase.

Kvalita života sa vplyvom rôznych ochorení vo všeobecnosti často znižuje, hlavne v porovnaní s bežnou populáciou. Po liečbe sa fyziologická kvalita života pacientov po prekonaní CMP môže zvýšit', ale psychologická kvalita zostáva spravidla nízka (Chen, et al., 2019). V štúdiách však väčšinou kvalita života so zameraním na zdravie (Health-Related Quality of Life) vystupuje ako závislá premenná (van Mierlo et al., 2015). V našom prípade bola kvalita života zist'ovaná v akútnej fáze po CMP a významný vzt’ah kzlepšenému funkčnému stavu po čase môže súvisiet' so špecifickou charakteristikou vnímania pacientov práve počas akútnej fáze. Lepšiu prognózu 
vzhl’adom k zlepšenej nezávislosti aktivít denného života majú pacienti s často horším hodnotením ich aktuálneho stavu, resp. kvality života.

Depresia po prekonaní CMP predstavuje pomerne bežnú reakciu, pričom v závislosti od vel'kosti vzorky a použitých nástrojov hodnotenia vedci zistili, že sa vyskytuje u $20 \%$ až $40 \%$ pacientov. Ďalším častým následkom prekonania CMP býva generalizovaná úzkostná porucha, ktorá sa vyskytuje u $20 \%$ až $30 \%$ pacientov v závislosti od času prekonania CMP (Chrki, Bullain \& Stern, 2006; Barker-Collo, 2007; Lincoln et al., 2013). Výskyt depresie a úzkosti tiež súvisí s nižšou kvalitou života (Peixoto et al., 2017). Podl’a našich zistení však zvýšená depresia a úzkost' v akútnej fáze priamo a významne nepredikuje zlepšenie funkčného ani kognitívneho stavu počas rekonvalescencie. Je možné, že práve vnímanie aktuálneho stavu v akútnej fáze ( $\mathrm{v}$ prípade nášho merania cca 5 dní po prekonaní CMP) je výrazne ovplyvnené aktuálnym stavom a nemusí nutne znamenat' dlhodobo pretrvávajúci negatívny dopad CMP.

Ako dôležité sa ukazujú rôzne stabilné osobnostné charakteristiky vzhl’adom na rôzne charakteristiky rekonvalescencie pacientov, najčastejšie však neurotizmus (van Mierlo et al., 2015, 2017; Solgajová et al., 2017). Uvedené výskumy sledujú väčšinou kvalitu života ako závislú premennú. Naše výsledky naznačujú, že aj iné osobnostné charakteristiky - ako napríklad otvorenost' voči skúsenosti - môžu predikovat' zlepšenie funkčného stavu počas rekonvalescencie pacientov po prekonaní CMP. Prekvapivým však bolo zistenie, že nízka úroveň otvorenosti predpovedá zlepšenie stavu po čase. Položky použitého meracieho stroja (mini IPIP) pre premennú Otvorenost' obsahovo zodpovedajú preferencii konkrétneho, resp. abstraktného myslenia, pričom nízke skóre naznačuje skôr praktické myslenie. Prediktorom zlepšenia funkčného stavu je teda skôr praktické nastavenie aj v myslení.

Dôležitou a skúmanou charakteristikou sú aj stratégie zvládania zát’aže, pričom proaktívne stratégie zvládania zát’aže sa vo viacerých štúdiách spájajú s lepším fyzickým stavom a rekonvalescenciou pri prekonaní zdravotných problémov a ochorení (Tielemans et al., 2015; van Mierlo et al., 2017). Napríklad u pacientov so sklerózou multiplex sa ukázalo, že tí ktorí využívajú proaktívne zvládanie majú lepší fyzický stav a prežívajú menej symptómov spojených s ochorením (Nowaczyk, Cierpialkowska, 2016). U pacientov po operácii kíbov sa zasa proaktívne zvládanie spájalo s lepším funkčným zotavením (Greenglass, Marques, de Ridder, Behl, 2005). Pri hodnotení proaktívneho zvládania sa však neukazuje pozitívny efekt na zlepšenie funkčného stavu pacientov po CMP. Je možné, že na rozdiel od napríklad operácie kíbov ide o iný typ procesu vo vzt’ahu k pozitívnemu efektu stratégií zvládania zát’aže.

Výskumy naznačujú, že zmeny funkčného stavu môžu súvisiet’ s vekom pacientov (Robinson, Jorge, 2016). Podl'a uvedenej štúdie sa funkčný stav zlepšil do 6 mesiacov po CMP u pacientov vo veku do 70 rokov a do 1 mesiaca po cievnej mozgovej príhody u pacientov nad 70 rokov. Tridsat' mesiacov po CMP nenastala žiadna významná zmena vo funkčnom stave u pacientov vo veku do 70 rokov (meranom Barthelovej indexom), zatial' čo u starších pacientov došlo k významnému poklesu funkčného stavu. Vek, ako aj iné demografické a klinické faktory si vyžadujú d'alšie preskúmanie.

Limitmi realizovanej štúdie sú predovšetkým relatívne menší rozsah výskumného súboru a sebavýpoved'ový charakter niektorých použitých meracích nástrojov. Hoci samotné vybrané meracie nástroje obsahujú pomerne jednoduché položky, ich použitie v akútnej fáze po CMP sa dá považovat’ za limitujúce.

\section{ZÁVER}

Hodnotenie rekoncalescencie pacientov po prekonaní CMP a skúmanie jeho možných prediktorov je dôležité pre ich d'alší život, ako aj z hl'adiska poskytovanej starostlivosti. Poznanie prediktorov 
pozitívnych zmien funkčného a kognitívneho stavu môže prispiet' k efektívnejšej starostlivosti o pacientov po CMP.

Vnímanie kvality života $v$ akútnej fáze po CMP môže predpovedat' pozitívne zmeny funkčného stavu pacientov. Poznanie d'alších potenciálnych prediktorov môže prispiet' kefektívnejšej starostlivosti o pacientov po CMP.

\section{LITERATÚRA}

Al-Qazzaz, N. K., Ali, S. H., Ahmad, S. A., Islam, S., \& Mohamad, K. (2014). Cognitive impairment and memory dysfunction after a stroke diagnosis: a post-stroke memory assessment. Neuropsychiatric disease and treatment, 10, 1677-1691. doi.org/10.2147/NDT.S67184

Andelic, N., Hammergren, N., Bautz-Holter, E., Sveen, U., Brunborg, C. \& Røe, C. (2009), Functional outcome and health-related quality of life 10 years after moderate-to-severe traumatic brain injury. Acta Neurologica Scandinavica, 120, 16-23. doi.org/10.1111/j.1600-0404.2008.01116.x

Azouvi, P., Ghout, I., Bayen, E., Darnoux, E., Azerad, S., Ruet, A., Vallat-Azouvi, C., Pradat-Diehl, P., Aegerter, P., Charanton, J., \& Jourdan, C. (2016). Disability and health-related quality-of-life 4 years after a severe traumatic brain injury: A structural equation modelling analysis. Brain injury, 30(1314), 1665-1671. doi.org/10.1080/02699052.2016.1201593

Barker-Collo S. L. (2007). Depression and anxiety 3 months post stroke: prevalence and correlates. Archives in Clinical Neuropsychology 22(4), 519-531. DOI: 10.1016/j.acn.2007.03.002.

Bode, C., Thoolen, B., \& de Ridder, D. (2008). Measuring proactive coping. Psychometric characteristics of the Utrecht Proactive Coping Competence scale (UPCC). Psychologie \& Gezondheid, 36(2), 81-91.

Bóriková, I. (2010). Posudzovanie aktivít denného života. Ošetrovatelství a porodní asistence, 1(1), 24-30.

Donnellan, C., Hickey, A., Hevey, D., \& O'neill, D. (2010). Effect of mood symptoms on recovery one year after stroke. International journal of geriatric psychiatry, 25(12), 1288-1295. DOI: 10.1002 /gps.2482

Ekker, M. S., Boot, E. M., Singhal, A. B., Tan, K. S., Debette, S., Tuladhar, A. M., \& de Leeuw, F.-E. (2018). Epidemiology, aetiology, and management of ischaemic stroke in young adults. The Lancet Neurology, 17(9), 790-801. doi:10.1016/s1474-4422(18)30233-3

Feigin, V. L., Roth, G. A., Naghavi, M., Parmar, P., Krishnamurthi, R., Chugh, S., ... Forouzanfar, M. H. (2016). Global burden of stroke and risk factors in 188 countries, during 1990-2013: a systematic analysis for the Global Burden of Disease Study 2013. The Lancet Neurology, 15(9), 913-924. doi:10.1016/s1474-4422(16)30073-4

Folstein, M. F., Folstein, S. E., \& McHugh, P. R. (1975). Mini-Mental State a Practical Method for Grading the Cognitive State of Patients for the Clinician. Journal of Psychiatric Research, 12(3), 189198.

Forslund, M. V., Roe, C., Sigurdardottir, S., \& Andelic, N. (2013). Predicting health-related quality of life 2 years after moderate-to-severe traumatic brain injury. Acta Neurologica Scandinavica, 128(4), 220-227. doi:10.1111/ane.12130

Grauwmeijer, E., Heijenbrok-Kal, M. H., Peppel, L. D., Hartjes, C. J., Haitsma, I. K., de Koning, I., \& Ribbers, G. M. (2018). Cognition, Health-Related Quality of Life, and Depression Ten Years after 
Moderate to Severe Traumatic Brain Injury: A Prospective Cohort Study. Journal of Neurotrauma, 35(13), 1543-1551. doi:10.1089/neu.2017.5404

Greenglass, E. R., Marques, S., deRidder, M., \& Behl, S. (2005). Positive coping and mastery in a rehabilitation setting. International Journal of Rehabilitation Research. Internationale Zeitschrift fur Rehabilitationsforschung. Revue internationale de recherches de readaptation, 28(4), 331-339. doi.org/10.1097/00004356-200512000-00005

Haagsma, J. A., Scholten, A. C., Andriessen, T. M. J. C., Vos, P. E., Van Beeck, E. F., \& Polinder, S. (2015). Impact of Depression and Post-Traumatic Stress Disorder on Functional Outcome and HealthRelated Quality of Life of Patients with Mild Traumatic Brain Injury. Journal of Neurotrauma, 32(11), 853-862. doi:10.1089/neu.2013.3283

Hackett, M. L., Köhler, S., O’Brien, J. T., \& Mead, G. E. (2014). Neuropsychiatric outcomes of stroke. The Lancet Neurology, 13(5), 525-534. doi:10.1016/s1474-4422(14)70016-x

Hullová, D., \& Duriš, R. (2017). Slovenská verzia dotazníku Mini IPIP. [online] [cit. 2019-10-12]. Dostupné na internete: http://ipip.ori.org/newItemTranslations.htm

Chen, Q., Cao, C., Gong, L., \& Zhang, Y. (2019). Health related quality of life in stroke patients and risk factors associated with patients for return to work. Medicine, 98(16), e15130. doi.org/10.1097/MD.0000000000015130

Chiang, C.-C., Guo, S.-E., Huang, K.-C., Lee, B.-O., \& Fan, J.-Y. (2015). Trajectories and associated factors of quality of life, global outcome, and post-concussion symptoms in the first year following mild traumatic brain injury. Quality of Life Research, 25(8), 2009-2019. doi:10.1007/s11136-0151215-0

Chriki, L. S., Bullain, S. S., \& Stern, T. A. (2006). The recognition and management of psychological reactions to stroke: a case discussion. Primary care companion to the Journal of clinical psychiatry, 8(4), 234-240. doi.org/10.4088/pcc.v08n0407

Kortte, K. B., Stevenson, J. E., Hosey, M. M., Castillo, R., \& Wegener, S. T. (2012). Hope predicts positive functional role outcomes in acute rehabilitation populations. Rehabilitation Psychology, 57(3), 248-255. doi:10.1037/a0029004

Lin, M. R., Chiu, W. T., Chen, Y. J., Yu, W. Y., Huang, S. J., \& Tsai, M. D. (2010). Longitudinal Changes in the Health-Related Quality of Life During the First Year After Traumatic Brain Injury. Archives of Physical Medicine and Rehabilitation, 91(3), 474-480. doi:10.1016/j.apmr.2009.10.031

Lincoln N. B., Brinkmann N., Cunningham S., Dejaeger E., De Weerdt W., \& Jenni W. (2013). Anxiety and depression after stroke: a 5 year follow-up. Disability 35(2), 140-145. doi:10.3109/09638288.2012.691939.

Maaijwee, N. A. M. M., Rutten-Jacobs, L. C. A., Arntz, R. M., Schaapsmeerders, P., Schoonderwaldt, H. C., van Dijk, E. J., \& de Leeuw, F.-E. (2014). Long-term increased risk of unemployment after young stroke: A long-term follow-up study. Neurology, 83(13), 1132-1138. doi:10.1212/wnl.0000000000000817

Mahoney, F. I., \& Barthel, D. W. (1965). Functional evaluation: The Barthel Index. Maryland State Medical Journal, 14(2), 61-65.

Molloy, D. W., Alemayehu, E., \& Roberts, R. (1991). Reliability of a Standardized Mini-Mental State Examination compared with the traditional Mini-Mental State Examination. American Journal Psychiatry, 148(1), 102-105. 
Nawaz, B., Eide, G. E., Fromm, A., Øygarden, H., Sand, K. M., Thomassen, L., Næss, H., \& WajeAndreassen, U. (2019). Young ischaemic stroke incidence and demographic characteristics - The Norwegian stroke in the young study - A three-generation research program. European Stroke Journal, 4(4), 347-354. https://doi.org/10.1177/2396987319863601

Nowaczyk, N. \& Cierpialkowska, L. (2016). Coping with multiple sclerosis from the perspective of Stevan E. Hobfoll's theory of conservation of resources. Advances in Psychiatry and Neurology, 25(2), 111-123.

Pagnini, F., Cavalera, C., Rovaris, M., Mendozzi, L., Molinari, E., Phillips, D., \& Langer, E. (2018). Longitudinal associations between mindfulness and well-being in people with multiple sclerosis. International Journal of Clinical and Health Psychology, 19(1), 22-30. doi:10.1016/j.ijchp.2018.11.003

Peixoto, B., Silvac, S., Carreirad, S., Sousae, D., Rezendef, V., \& Teixeiraf, A. (2017). Quality of life predictors after first stroke: A study with post-acute patients. Neurology, Psychiatry and Brain Research, 23, 10-15.

Post, M. W, Boosman H., Van Zandvoort M. M., Passier P. E., Rinkel G. J., \& Visser-Meily J. M. (2011). Development and validation of a short version of the Stroke Specific Quality of Life Scale. Journal Neurology, Neurosurgery \& Psychiatry, 82(3), 283-286. DOI: 10.1136/jnnp.2009.196394.

Robinson, R. G., \& Jorge, R. E. (2016). Post-Stroke Depression: A Review. American Journal of Psychiatry, 173(3), 221-231. doi:10.1176/appi.ajp.2015.1503036

Rejnö, Å., Nasic, S., Bjälkefur, K., Bertholds, E., \& Jood, K. (2019). Changes in functional outcome over five years after stroke. Brain and behavior, 9(6), e01300. https://doi.org/10.1002/brb3.1300

Solgajová, A., Sollár, T., Vörösová, G., \& Zrubcová, D. (2017). Personality as significant predictor of post-stroke anxiety. Neuroendocrinology Letters, 38(4), 290-294.

Sollár, T., Dančová, K., Solgajová, A., \& Romanová, M. (in press) Depression and anxiety as predictors of quality of life after a stroke. Kontakt, 1-6. http://doi.org/10.32725/kont.2022.002

Tabachnick, B. G., \& Fidell, L. S. (2007). Using multivariate statistics (5th ed.). Allyn \& Bacon/Pearson Education.

Tielemans, N. S., Schepers, V. P., Visser-Meily, J. M., Post, M. W., \& Van Heugten, C. M. (2015). Associations of proactive coping and self-efficacy with psychosocial outcomes in individuals after stroke. Archives of physical medicine and rehabilitation, 96(8), 1484-1491. DOI: 10.1016/j.apmr.2015.04.009

van Mierlo, M. L., Van Heugten, C. M., Post, M. W., De Kort, P. L., \& Visser-Meily, J. M. (2015). Psychological factors determine depressive symptomatology after stroke. Archives of physical medicine and rehabilitation, 96(6), 1064-1070. DOI: 10.1016/j.apmr.2015.01.022

van Mierlo, M., Van Heugten, C. M., Post, M. W., Hoekstra, T., \& Visser-Meily, A. (2017). Trajectories of health-related quality of life after stroke: results from a one-year prospective cohort study. Disability and rehabilitation, 40(9), 997-1006. DOI: 10.1080/09638288.2017.1292320

Wang, H. X., Zhang, W. R., Yang, X. T., Ma, Q. F., Song, H. Q., Zhang, D. L., Jorge, R. E., Zhu, S. Q., Zhu, Z., Wang, Y. P., \& Xie, P. (2019). Zhonghua yi xue za zhi, 99(21), 1611-1614. doi.org/10.3760/cma.j.issn.0376-2491.2019.21.004 
Wang, W., Jiang, B., Sun, H., Ru, X., Sun, D., Wang, L., ... Feigin, V. L. (2017). Prevalence, Incidence, and Mortality of Stroke in ChinaClinical Perspective. Circulation, 135(8), 759-771. doi:10.1161/circulationaha.116.02

Yeoh, Y. S., Koh, G. C.-H., Tan, C. S., Tu, T. M., Singh, R., Chang, H. M., ... Luo, N. (2019). Health-related quality of life loss associated with first-time stroke. PLOS ONE, 14(1), e0211493. doi:10.1371/journal.pone.0211493

Zigmond, A. S., \& Snaith, R. P. (1983). The hospital anxiety and depression scale. Acta Psychiatrica Scandinavica 67(6), 361-370. DOI: 10.1111/j.1600-0447.1983.tb09716.x.

\section{PREDICTORS OF FUNCTION AND COGNITIVE CHANGE IN PATIENTS AFTER STROKE}

\section{Abstract}

Background: Patient recovery after a stroke is crucial for their future life. Knowing the predictors of positive functional and cognitive changes can contribute to more effective patient care after a stoke.

Aim: The aim of the study is to examine changes in functional and cognitive status and their prediction by psychological variables (depression, anxiety, quality of life, proactive coping and personality characteristics) evaluated in the acute phase of the disease.

Methods: The sample consisted of a total of 127 patients after a stroke, of which $60 \%$ were men, the average age of patients was 67.1 years. The first measurement was performed in the acute phase 72 hours after a stroke; second measurement at the check-up within 1 year after a stroke. Total number of repeated measurements $n=57$, for the combination of all monitored variables $n$ $=40$. The Barthel ADL scale, Mini-Mental State Examination, Hospital Anxiety and Depression Scale, Stroke Specific Quality of Life Scale, Utrecht Proactive Competence Coping Scale and Mini IPIP were used for data collection. The research was approved by the Ethics Committee.

Results: The evaluated psychological predictors of functional status show that quality of life in the acute phase after a stroke and personality characteristics openness to experience were statistically significant predictors. Changes in cognitive status in the acute phase and at the time of the first follow-up appear to be statistically nonsignificant. The results suggest that changes are not statistically significantly predictable by the observed psychological variables.

Implications: Perception of quality of life in the acute phase after a stroke can predict positive changes in patients' functional status. Knowing other potential predictors may contribute to more effective patient care after a stroke.

Key words: Stroke. Functional status. Personality. Quality of life. Anxiety. Depression.

\section{Grantová podpora:}

Príspevok vznikol ako súčast' riešenia grantového projektu VEGA 1/0418/19 Zvládanie zát'aže v procese rekonvalescencie po cievnej mozgovej príhode. 